

\section{MAYA ANGELOU E A ESCRITURA DA MULHER QUE SE LEVANTA}

\author{
Lunara Carolline Nascimento Gomes ${ }^{1}$
}

o elo que torna algumas das vivências das mulheres negras estadunidenses um coro em uníssono. Tratarei aqui, nesta resenha, de alguns dos pontos em comum que podemos visualizar através da leitura de teóricas feministas negras como, por exemplo, Bell Hooks e Patricia Hill Collins.

É necessário ressaltar que muitos dos poemas que utilizarei aqui serão recortados visto que a poetisa apresenta uma característica preponderante relacionada ao desenvolvimento de poemas longos. Entretanto, essa característica não denota que a autora faça uso de uma linguagem tida como hermética, pelo contrário, sua poesia de versos livres almeja ser compreendida em sua própria naturalidade, a qual está intrinsecamente relacionada ao perceber-se e sentir-se negra em um país como os Estados Unidos. Nesse sentido, o poema Estados Unidos da América apresenta trechos como: "O ouro de sua promessa nunca foi extraído/O limite de sua justiça não está bem definido/Suas colheitas abundantes a fruta e o grão/Não alimentaram os famintos nem aliviaram sua dor profunda/Suas promessas orgulhosas são folhas ao vento/Sua orientação segregacionista é amiga da morte de negros/Descubra este país os séculos mortos choram (ANGELOU, 2020, p. 99)”.

Do racismo institucional que perpetua desigualdades, injustiças e segregações se verifica também a manutenção de um imaginário social que insiste em condenar e responsabilizar os afro-americanos por sua descendência africana. A herança deixada pelo sistema escravocrata e que se expõe através de diferentes tipos de racismo leva a autora a refletir sobre o fato de se sentir culpada por causa da cor de sua pele: "Minha culpa são "as correntes da escravidão", por muito tempo/O barulho do ferro caindo ao longo dos anos./Este

${ }^{1}$ Doutoranda em Teoria da Literatura, pelo Programa de Pós-Graduação em Letras, da Universidade Federal de Pernambuco (PPGL - UFPE). 
irmão vendido, esta irmã que se foi,/Tornam-se uma cera amarga tapando os meus ouvidos./Minha culpa fez música com as lágrimas (ANGELOU, 2020, p. 61)”.

A culpa geradora de sofrimento e imputada aos africanos e seus afrodescendentes por séculos de exploração se transforma, no que podemos generalizar, em arte. É através, especificamente, da poesia que Maya Angelou lida com suas dores e estabelece pontes com o pensamento feminista negro. No poema Mais uma rodada, ela subverte parte do imaginário social que determina a subjugação dos indivíduos negros mas, aqui, vou focar na estrofe em que ela consolida: "E agora vou contar qual é minha Regra de Ouro,/Eu nasci para trabalhar, mas não sou nenhuma mula./Eu nasci para trabalhar até morrer/Mas não nasci/Para morrer escrava (ANGELOU, 2020, p. 167)".

Essa parte do poema encontra eco na obra de Patricia Hill Collins (2019), onde a autora se propõe a discutir uma questão fundamental para a teoria feminista: o trabalho destinado às mulheres negras. A autora define a posição das mulheres negras, associando o trabalho exercido por elas, como "mulas do mundo". Essas mulheres são tratadas, muitas vezes, como objetos desumanizados e como parte do cenário (COLLINS, 2019, p.99). Em relação ao tipo de trabalho, a teórica define da seguinte maneira:

Parece-nos mais apropriado conceber o que é trabalho considerando as várias formas de trabalho que as afro-americanas de fato exercem. $\mathrm{O}$ trabalho na forma de trabalho alienado pode ser economicamente explorador, fisicamente exigente e intelectualmente sufocante - o tipo de trabalho que há muito tempo é associado à condição da mulher negra como "mula" (COLLINS, 2019, p. 104).

Além disso, esse trabalho realizado pelas mulheres negras pobres, é percebido como semelhante ao trabalho doméstico. É importante destacar que, anteriormente, o serviço doméstico era uma atividade estritamente realizada em residências particulares. Contemporaneamente, os trabalhos são relacionados a atividades ligadas à limpeza, enfermagem e cuidado de crianças, por exemplo, e foram descentralizados em diferentes espaços (COLLINS, 2019, p.126).

A precária remuneração ou a falta dela em determinadas funções no mercado de trabalho se tornaram, de fato, uma importante questão para os estudos sociológicos, feministas e encontram espaço também na poesia de Maya Angelou. Nós podemos perceber outras conexões entre a obra poética e a teoria feminista negra, por exemplo, no que se refere à violência de gênero.

Bell Hooks (2020), por sua vez, tece uma crítica contundente em relação às mulheres das classes alta e média que estavam à frente do movimento feminista contemporâneo, no que 
concerne à pouca atenção dada às discussões sobre violência de gênero. Esse tipo de violência explicada pelo poder patriarcal é contextualizada pela autora e abarca o poder que todos os homens usam para subjugar e violentar mulheres, independentemente de classe ou raça (HOOKS, 2020, p.145):

Muito da violência contra mulheres nesta cultura é promovida pelo patriarcado capitalista que incentiva homens a se verem como privilegiados, enquanto diariamente os destitui de humanidade em trabalhos desumanos e, como consequência, eles usam violência contra mulheres para resgatar o senso de poder e masculinidade que perderam (HOOKS, 2020, p.173).

Faz-se necessário evidenciar aqui que o patriarcado pode se manifestar de diferentes maneiras e devemos levar em consideração as distintas masculinidades e relações sociais/ afetivas. No entanto, uma das justificativas dada pela autora para a violência de gênero é fruto, portanto, da união do patriarcado com o sistema capitalista. Nesse sentido, o trecho do poema abaixo estabelece uma interessante aproximação com a discussão desenvolvida por Bell Hooks (2020): “Coleridge Jackson não tinha nada/a temer. Ele pesava trinta quilos/a mais que seus filhos e quarenta e cinco quilos/a mais que sua esposa./Todos na vizinhança se perguntaram/por que Coleridge voltaria para casa,/tiraria sua jaqueta, tiraria/seus sapatos e daria/uma surra na sua pequena/família frágil (ANGELOU, 2020, p. 248)”.

Nesse poema, Maya Angelou descreve o cotidiano de um trabalhador negro chamado Coleridge Jackson e seu chefe, "um saquinho branco de ossos", que ataca ferozmente Coleridge, o chamando de "preto deplorável" e de "preto preguiçoso". Entretanto, Coleridge não se permite revidar os atos racistas de seu chefe, mantendo sua boca fechada e seu olhar mirando outro lugar. Sua família torna-se assim, o alvo de sua raiva e vingança.

Nota-se, portanto, uma série de poemas de Maya Angelou que trazem debates e preocupações próprias do pensamento feminista estadunidense. De maneira geral, a partir de sua obra, nos aproximamos de um processo amplo de desconstrução de estereótipos e memórias sociais de um passado escravocrata que fincou suas raízes de maneira bastante bruta e eficaz. Faz-se necessário destacar a potencialidade da obra poética em toda sua diversidade, afirmando nesse sentido, que os diálogos entre as distintas obras não se encerram aqui. Por vezes a leitura de seus poemas nos causa doloridas e indispensáveis reflexões, corroborando a urgência do conhecimento e reconhecimento de uma das maiores vozes femininas negras da literatura estadunidense. 


\section{REFERÊNCIAS}

ANGELOU, M. Poesia completa. Bauru, SP: Astral Cultural, 2020.

COLLINS, P. H. Pensamento feminista negro: conhecimento, consciência e a política do empoderamento. 1. ed. São Paulo: Boitempo, 2019.

HOOKS, B. E eu não sou uma mulher?: mulheres negras e feminismo. 2. ed. Rio de janeiro: Rosa dos tempos, 2020.

Recebido: $16 / 09 / 2020$

Aprovado: 08/12/2020 